\title{
JURNALISME KLONING DI KALANGAN WARTAWAN KOTA SURAKARTA
}

\section{CLONING JOURNALISM IN SURAKARTA JOURNALIST}

\author{
Erwin Kartinawati \\ (erwinpurwasito@gmail.com) \\ (Program Studi Ilmu Komunikasi, Universitas Sahid Surakarta)
}

\begin{abstract}
Abstrak
Berita memegang peranan di masyarakat. Tidak hanya sebagai sumber informasi, namun berita dapat mempengaruhi masyarakat di tataran kognitif hingga afektif. Media tidak hanya menjadi yang pertama dalam menyajikan berita, namun juga menjadi satu-satunya yang dapat menyajikan berita tertentu. Sayang, demi tujuan memenuhi target perolehan berita, tidak semua wartawan menjalankan profesinya secara jujur, menyajikan berita hasil perolehan/liputan sendiri. Cloning journalism adalah salah satu praktik yang dilakukan oleh sebagian wartawan dimana mereka tidak terjun langsung melakukan proses peliputan, namun tetap mendapatkan beritanya. Cloning journalism tidak hanya melanggar kode etik tentang jurnalistik, juga merugikan perusahaan media bersangkutan. Pola-pola cloning journalism dilakukan dalam berbagai bentuk. Mengenai penyebab adalah berkaitan dengan aturan perusahaan media, simbiosis mutualisme, serta motif ekonomi.
\end{abstract}

Kata Kunci: Jurnalisme Kloning, Etika, Profesionalisme Media

\begin{abstract}
News plays role in society. Not only as a source of information but it also can affect people in the cognitive until affective level. Media is not only being the first to present news but also the only one who can present particular news. Unfortunately, for the purpose of fulfilling the target acquisition news, not all of journalists carrying out their profession honestly, presenting news result of the acquisition of its own. Cloning journalism is one of the practices made by some journalists where they do not plunge directly to the process of information gathering, but still get the story. Cloning journalism not just opposite to code of ethics of journalism but also detrimental to media companies concerned. Patterns of cloning journalism carried out in various forms. Regarding the cause are related to the rules of the media company, symbiotic mutualism, and as well as economic motives.
\end{abstract}

Keywords: Cloning Journalism, Ethics, Media Professionalism

\section{Pendahuluan}

Berita merupakan salah satu produk media massa. Berita diakui memiliki peranan penting dalam kehidupan masyarakat saat ini. Ia mempengaruhi berbagai sendi baik dalam tataran kognitif maupun afektif dalam arti mampu mempengaruhi pikiran hingga dalam wujud tindakan. Kehidupan masyarakat yang semakin individualistik membuat masyarakat bergantung pada berita sebagai sumber informasi. Banyak dari suatu anggota masyarakat tidak tahu menahu mengenai suatu hal yang terjadi di dekat lingkungan mereka secara langsung namun justru dari berita baik yang disiarkan lewat

televisi, radio, internet, koran, dan sebagainya.

Berita tidak sekadar sebagai sumber informasi masyarakat namun melalui berita, kebijakan-kebijakan penting dibuat pemerintah juga didasarkan pada terpaan media dan respons masyarakat pasca melihat tayangan berita. Berita mampu membuat masyarakat bertindak, memberikan respons positif maupun sinis atas kebijakan (Vreese, 2004: 191-214). Melihat peran berita yang begitu strategis di masyarakat, tak mengherankan banyak dari media yang kemudian menjadikannya sebagai produk unggulan, dengan 
memposisikan diri sebagai media khusus penyedia (penyampai, pemroduksi) berita. Berita menjadi komoditas andalan. Tidak hanya di Indonesia namun juga luar negeri seperti BBC, Sky News, Fox News, Aljazeera, Bloomberg, France 24, CNN, CNBC, Channel News Asia, dan masih banyak lagi.

Oleh karena menjadi komoditas andalan, itulah yang menyebabkan setiap media berlomba-lomba, adu cepat dalam menyiarkan suatu informasi (berita) baik melalui siaran langsung, breaking news, running text, maupun menayangkannya dalam program berita terawal. Inilah yang kemudian disebut dengan konsep ekslusif dalam media. Tak hanya sebagai media tercepat atau terawal dalam menyampaikan suatu berita, ekslusifitas media dalam menyampaikan berita kepada masyarakat juga dilakukan dengan cara menyajikan berita secara berbeda, tidak dimiliki media lain. Karena itulah sering kita melihat adanya tulisan baik "eksklusif" di layar kaca televisi atau koran (wawancara ekslusif, liputan ekslusif, dsb). Dengan ekslusif dalam waktu penyampaian maupun materi berita, diharapkan dapat menggaet minat khalayak. Minat merupakan kata sakti bagi media karena sebagai kunci mendapatkan iklan. Iklan adalah sumber utama pemasukan bagi media agar tetap terus beroperasi.

Pada industri media, eksklusifitas baik dari segi materi maupun waktu penayangan yakni menjadi yang pertama dan satu-satunya menayangkan (memberitakan) merupakan doktrin utama pengelola media terhadap para wartawannya. Ekslusifitas tidak hanya berkaitan dengan citra atau gengsi media karena mampu menyajikan sesuatu yang tidak dimiliki media lain. Ekslusifitas berita juga terkait ketat dengan persaingan bisnis media. Media yang mampu menyajikan berita secara ekslusif logikanya akan mampu mencuri perhatian khalayak. Khalayak inilah yang kemudian berkaitan dengan rating dan rating merupakan kunci masuknya iklan. Sebagaimana dikemukakan di atas, iklan menjadi salah satu bagian terpenting dalam keberlangsungan industri media massa.

Perihal ekslusifitas ini biasanya menjadi bagian materi dalam pembekalan atau pelatihan bagi insan media khususnya jurnalis saat awal diterima bergabung atau bekerja di bidang jurnalistik. Bila salah satu media mampu menyajikan berita secara ekslusif namun tidak bagi media lain, maka ini akan menjadi semacam "dosa besar" yang tidak terampuni bagi jurnalis bertugas di bidangnya, atau, bahkan bisa dianggap sebagai sebuah badai yang telah menghancurkan citra maupun idealisme media yang tidak mendapatkan suatu berita dengan tema tertentu tersebut. Setiap wartawan pasti mendapat doktrin dari pihak redaksi untuk mendapatkan berita secara ekslusif, dan menyiarkannya secara eksklusif pula. Sayang, praktik di lapangan tidaklah seperti itu. Banyak wartawan bekerja secara bersama dalam perolehan berita sehingga yang terjadi adalah seperti yang sering kita lihat baik di koran maupun televisi. Semua media memberitakan hal yang sama, bahkan terkadang hingga judul dan pemilihan angel dan lead (kepala/inti berita utama) sama. Yang terparah adalah kadang ditemui adanya persamaan tak hanya dalam angel maupun lead, judul namun hingga kutipan, ejaan bahkan titik dan koma. Mengapa demikian? Jurnalisme kloning adalah salah satu penyebabnya. istilah kloning berita merujuk pada perilaku wartawan yang melakukan copy paste (menjiplak) berita wartawan media lain tanpa melakukan proses peliputan sendiri atau tidak maksimal dalam proses mendapatkan bahan, kemudian menggunakan bahan dan atau berita tersebut untuk disiarkan/dimuat di medianya dengan menggunakan nama wartawan yang melakukan copy paste (kloning) (Syah, 2011). Dengan demikian, yang terjadi wartawan tersebut tetap 
mendapatkan suatu berita tanpa harus melakukan proses peliputan sendiri.

Praktik kloning berita layaknya sudah menjadi budaya atau kebiasaan yang terulang, terus terjadi dan dianggap lazim oleh kalangan wartawan. Sejatinya, praktik kloning dalam rangka mendapatkan berita ini merugikan wartawan yang dijiplak beritanya tetapi juga berisiko terhadap pelaku kloning terutama bila terdapat kekeliruan dalam hal penulisan maupun isi berita sehingga memunculkan protes dari pihak diberitakan. Ketidakpuasan pihak diberitakan dapat berujung persoalan hukum terutama bila berkenaan dengan pencemaran nama baik dan lain sebagainya. Praktik kloning pada dasarnya merupakan bentuk plagiat karena menyatakan hasil liputan wartawan lain sebagai karya sendiri dan itu tidak dibenarkan dalam kode etik jurnalistik. Pasal 2 kode etik jurnalistik mengharuskan wartawan Indonesia menempuh cara-cara yang profesional dalam melaksanakan tugas jurnalistik. Cara-cara yang profesional ini salah satunya ditafsirkan dengan bekerja secara jujur, tidak melakukan plagiat, termasuk menyatakan hasil liputan wartawan lain sebagai karya sendiri.

Praktik kloning berita adalah hal dilarang namun faktanya praktik itu terus terjadi dan dilakukan oleh kalangan wartawan. Budaya kloning berdampak pada hilangnya ekslusifitas berita yang justru menjadi sumber andalan media dalam menjual berita kepada khalayak.

\section{Metodologi}

1. Metode Autoetnografi

Kajian ini menggunakan metode etnografi, atau lebih tepatnya autoetnografi. Autoetnografi merupakan bentuk aplikasi dari etnografi yang pada intinya sama dengan metode etnografi itu sendiri. Yang membedakannya adalah data dalam kajian merupakan hasil ingatan (memori) dari peneliti berdasarkan pengalaman peneliti tentang hal tertentu.
Metode ini memberi ruang dan kesempatan bagi penulis atau peneliti untuk menggunakan suara dan pengalaman pribadinya untuk lebih memahami lingkungan atau situasi budaya yang ada di sekitarnya (Chang, 2008). Singkatnya, autoetnografi berangkat dari pengalaman penulis mengenai suatu fenomena namun tidak menutup kemungkinan penulis kembali terjun ke lapangan untuk melakukan observasi, pencocokan dan pembaruan data.

Autoetnografi memiliki beberapa hal yang menjadi prioritas, perhatian, caracara dalam melakukan penelitian (Adams, Jones dan Ellis, 2015: 26) yakni :

1.1. Mengedepankan pengalaman pribadi dalam penelitian dan penulisan.

1.2. Menggambarkan pembentukan makna.

1.3. Menggunakan dan menunjukkan refleksifitas.

1.4. Menggambarkan pengetahuan dari orang dalam (insider) dari suatu fenomena budaya/pengalaman.

1.5. Mendeskripsikan dan mengkritisi norma budaya, pengalaman, dan kebiasaan.

1.6. Mencari respon dari pembaca

Penelitian autoetnografi adalah aplikasi dari etnografi. Etnografi digunakan untuk menggambarkan polapola komunikasi, perilaku, atau kebiasaan pada suatu anggota kelompok masyarakat atau kebudayaan tertentu. Etnografi secara etimologi berasal dari tiga kata yakni "ethno", "method" dan "ology" yang pada dasarnya memiliki tujuan sebagai alat penjelas (explanation) mengenai suatu etnik atau kelompok kesukuan. Kata "ethno" atau "etnik" saat ini tidak lagi sekedar dimaknai sebagai suatu kesukuan atau kelompok yang mendiami daerah tertentu namun bisa mengacu pada bagian suatu kelompok sosial dalam pengertian yang lebih luas (Lynch, 1993). Dari pengertian di atas dapat disimpulkan jika kajian ini termasuk dalam kajian etnografi. Arti etno dalam kajian ini tak lagi sekadar 
merujuk pada kesukuan atau bagian bangsa tertentu namun kelompok, dalam hal ini adalah kelompok atau komunitas wartawan yang ada di Kota Surakarta. Hal yang dikaji adalah persoalan perilaku atau kebiasaan dilakukan dalam hal mendapatkan berita.

Apa yang dilihat oleh peneliti dengan metode etnografi adalah (1) bagaimana atau seperti atau bentuk (pola) perilaku atau komunikasi yang digunakan oleh suatu kelompok; (2) Arti atau makna dari pola yang dimiliki suatu kelompok tersebut; (3) Kapan dan di mana anggota kelompok mempraktikkan pola-pola dimaksud; (4) bagaimana pola tersebut menciptakan sebuah perasaan/ikatan tertentu dalam komunitas; (5) kode-kode apa yang digunakan oleh suatu kelompok atau komunitas (Littlejohn, 2011: 385386). Yang pasti alat utama dalam metode ini adalah keterlibatan peneliti (participant observation) dalam hal pengumpulan data yangmana apa yang diamati bisa apapun seperti kepercayaan hidup, nilai-nilai serta praktik atau perilaku. Keterlibatan peneliti dalam melakukan observasi ini harus dilakukan secara simultan atau terus menerus untuk mendapatkan sudut pandang yang tepat tentang tema diamati (Hume and Mulcock, 2004). Peneliti harus aktif terjun ke lapangan untuk mengamati obyek, melakukan wawancara informal, mengembangkan daya ingat, membuat catatan-catatan, juga harus bersabar. Participant observation pada dasarnya adalah kajian atropologi model kualitatif, lebih tepatnya disebut dengan etnografi.

Model penelitian dengan autoetnografi memang belum lama namun sudah banyak yang mencoba menerapkannya. Salah satunya adalah penelitian yang ditulis Assistant Professor School of Education at New York Institute of Technology, di New York, AS, Kate O'Hara sebagaimana termuat dalam Journal of Arts and Humanities (JAH), Volume 3, No. 6, (June 2014: 9-15), Dengan judul From Filtering to Freire:
Critical Use of the Internet in Urban Classrooms. Dalam tulisan itu, dengan menggunakan metode autoetnografi, O'Hara menuliskan pengalaman dan memberikan refleksinya sebagai seorang pengajar tentang penggunaan internet sebagai media pembelajaran di sekolah yang berada di Distrik K-22 AS. Bahwa internet sejatinya tak sekadar sebagai wajah baru dari model pembelajaran lama (konvensional) namun merupakan suatu pedagogi kritis karena jika diperdayakan secara maksimal dapat mengubah pola kekuasaan yang selama ini didominasi oleh guru terhadap siswa, mengontrol pola pembelajaran dan pemahaman guru, mode efektif dalam belajar dan pembelajaran siswa. Berangkat dari membaca tulisan O'Hara inilah penulis mencoba menerapkan metode serupa dalam penelitian komunikasi yakni tentang praktik dan pandangan komunitas wartawan Kota Surakarta mengenai kloning berita (cloning journalism).

\section{Bahan dan Cara Penelitian}

Bahan penelitian didapat berdasar pengalaman penulis sebagai jurnalis atau wartawan selama tahun 2003-2012. Meski merupakan hasil pengalaman di masa lampau namun penulis juga melakukan proses pengamatan kembali ke lapangan (observasi) dan melakukan wawancara terhadap para wartawan yang bekerja di wilayah Kota Surakarta, guna penggalian data lebih dalam. Data digali tidak sebatas terhadap wartawan atau jurnalis yang yang hanya bekerja di lapangan (reporter) namun juga yang bekerja di tingkatan redaksi. Meski begitu, wawancara tidak dilakukan terhadap seluruh jurnalis yang bekerja di wilayah kota ini maupun semua media yang berkantor di Kota Bengawan, tetapi berdasarkan sampel .

Sampel diambil berdasarkan aspek kemudahan (available sampling/ convenience sampling) dimana periset bebas memilih siapa saja anggota populasi dikarenakan data berlimpah (Kriyantono, 2010: 160). Teknik ini diambil karena 
praktik (budaya) kloning berita dilakukan oleh hampir semua wartawan, sudah dianggap sebagai hal biasa, rahasia umum meski pada dasarnya hal tersebut tidak diperbolehkan baik oleh masing-masing pengelola media maupun dari sisi kode etik jurnalistik berlaku. Dengan demikian, cara pengambilan sampel tidak mempengaruhi hasil kajian sebab berlaku sama pada semua media dan wartawan.

\section{Hasil dan Pembahasan}

Media massa atau pers menurut definisi Undang-Undang Pers No. 40/1999 sebagaimana termuat dalam pasal 1 ayat 1 adalah lembaga sosial dan wahana komunikasi massa yang melaksanakan kegiatan jurnalistik, meliputi mencari, memperoleh, memiliki, menyimpan, mengolah dan menyampaikan informasi baik dalam bentuk tulisan, suara, gambar, suara dan gambar, serta data dan grafik maupun dalam bentuk lainnya dengan menggunakan media cetak, media elektronika, dan segala jenis saluran tersedia. Jika media massa atau pers adalah lembaga maka wartawan adalah orang yang bekerja di lembaga media yang melakukan tugas-tugas jurnalistik sebagaimana tersebut di atas. Apa yang dicari, diperoleh, disimpan dan disiarkan itulah yang disebut dengan berita. Merujuk pada definisi UU Pers di atas maka sudah seharusnya dan selayaknya tugas jurnalistik mulai dari mencari, memperoleh, menyimpan, mengolah, dan menyampaikan berita kepada khalayak adalah hal yang harus dilakukan sendiri oleh wartawan.

\section{Praktik Kloning Berita}

Seperti telah disinggung pada bagian awal, tidak semua wartawan "berjuang" sendiri dalam memperoleh berita. Begitupun dalam menyimpannya untuk diteruskan ke dapur redaksi masingmasing. Fakta di lapangan, banyak wartawan bekerja bersama dalam hal perolehan berita sebelum akhirnya disusun dan diteruskan ke redaksi media bersangkutan. Bekerja bersama ini bisa dalam banyak bentuk mulai dari liputan bersama dengan media lain dengan kata lain "nongkrong" atau menunggui narasumber, wawancara beramai-ramai dengan topik sama, hingga meminta berita kepada wartawan media lain. Nongkrong bersama, menunggui narasumber dan mewancarai secara bersama-sama bahkan hingga mengetik berita secara bersamasama tentu bukanlah hal dilarang dan itu sudah menjadi bagian kerja jurnalis. Namun yang menjadi persoalan adalah ketika ada wartawan tidak datang ke lokasi melakukan proses peliputan sendiri, atau datang ke lokasi peliputan namun terlambat sehingga luput dalam hal pengamatan dan wawancara dengan narasumber, kemudian meminta bahan maupun berita kepada wartawan yang lain, inilah awal dari budaya kloning berita yang terjadi.

Kloning berita dilakukan dalam rangka supaya tetap mendapatkan suatu berita sekalipun tidak melakukan proses peliputan sendiri. Tentu ini adalah sebuah proses curang karena bentuk pembohongan terhadap masyarakat maupun redaksi. Meski melanggar etika, praktik ini seolah sudah membudaya dan tetap terjadi di kalangan wartawan, tidak terkecuali pada komunitas wartawan yang bekerja di wilayah Kota Surakarta. Cara dilakukan supaya tetap mendapatkan berita tanpa harus peliputan sendiri itu dapat dilihat dalam beberapa pola yang sama setiap praktiknya. Pertama adalah dengan meminta wartawan lain mentransfer materi wawancara secara oral. Dalam pola ini, wartawan yang melakukan proses peliputan menceritakan kembali apa yang didapat dalam proses peliputan kepada wartawan yang meminta bahan berita tadi. Dari situlah wartawan yang meminta tadi akan mampu menulis berita untuk disampaikan kepada redaksi. Pada proses penceritaan ulang bahan berita, wartawan yang meminta biasanya akan menyiapkan alat catat biasanya berupa pena, dan kertas 
namun terkadang mencatatnya dengan pikiran (mengingat-ingat), atau merekam suara wartawan pemberi berita melalui recorder atau langsung mengetiknya melalui fasilitas yang ada pada telepon seluler. Pola kedua dengan mendengarkan rekaman atau melihat gambar wawancara yang telah disimpan dalam media rekam atau bentuk digital lain. Pola ketiga dan ini adalah bentuk paling parah yakni tidak berupaya meminta materi berita namun meminta untuk dikirim naskah berita jadi dan menunggu kiriman lewat email dari wartawan lain. Setelah mendapat kiriman email tersebut akan diubah dengan kalimat sendiri, pada bagian akhir naskah atau awal akan diberi nama atau kode wartawan bersngkutan, seolah merupakan karya jurnalistiknya sendiri. Kiriman e-mail ini bisa berupa hanya berujud naskah atau inti-inti berita namun bisa juga berisi capture gambar hingga dalam bentuk naskah berita full (berita jadi). Untuk wartawan elektronik, menjadi hal biasa bagi mereka untuk tukar menukar atau pinjam meminjam gambar, atau merekam ulang hasil rekaman suara dari narasumber untuk wartawan radio. Untuk wartawan foto, biasanya berupa tukar menukar foto masih dalam tema sama namun biasanya disiasati dengan memberikan angel (sudut pengambilan obyek) yang lain. Cara ini dilakukan supaya tidak terlihat sama dengan foto media lain, atau bekerja dengan cara sendiri.

Seiring perkembangan tehnologi dalam bidang komunikasi khususnya praktik kloning berita juga mengalami perubahan. Tidak hanya dilakukan dalam pola konvensional namun juga menyesuaikan kekinian. Kehadiran internet dinilai sangat membantu bagi wartawan. Selain email, praktik kloning dimudahkan dengan adanya media sosial serta media online. Aplikasi yang sering dipakai untuk berbagi berita ini selain email yakni WhatsApp. Lainnya adalah dengan cara mengambil berita wartawan lain yang sudah lebih dahulu tayang/muat.
"Iya, biasanya suruh ngambil sendiri. Copy paste, tinggal ubah sana sini, selesai. Tapi ya bilang dulu kalau mau minta," kata narasumber kedelapan.

Kloning berita tidak digunakan sebagai istilah untuk menggambarkan praktik di atas bagi wartawan. Karena lokasi kajian di Surakarta yang merupakan bagian dari Jawa maka istilah kloning berita merujuk pada kosakata yang ada pada bahasa Jawa. Istilah yang digunakan yang biasa digunakan mereka saat meminta berita adalah "njuk", "bagi", "kirimi", dan "bandemi". Kemudian istilah digunakan untuk menyebut berita hasil kloning adalah "bandeman". "Bandeman" adalah istilah dalam Bahasa Jawa merupakan kata benda dari "bandemi" (kata kerja), yang berarti melempar benda/barang ke sesuatu atau orang lain sementara "bandeman" adalah hasil lemparan tersebut. Untuk memudahkan dalam memahami istilah itu dapat dilihat dalam kalimat tersebut. Seorang wartawan yang tengah menunggu berita kiriman wartawan lain biasanya akan berkata demikian,"aku lagi nunggu bandeman". Atau "aku mau entuk bandeman soko....", atau juga "arep bandeman ora?" bila menawari rekan lainnya suatu berita.

Fakta ini tentu sangat bertentangan dengan idealisme dan jauh dari kata eksklusif. Dengan liputan bersama, sekalipun membuat beritanya sendiri (hasil foto, rekam, tulisan) namun hasil yang diberitakan akan kurang lebih sama dengan apa yang diberitakan oleh media lainnya. Jika begini yang terjadi, darimana akan didapat ekslusif itu?. Meski sudah menjadi hal lazim dan dianggap biasa bagi kalangan wartawan, praktik kloning berita ini tidak bisa dilakukan oleh semua wartawan begitu saja. Wartawan yang dapat meminta berita wartawan lain hanyalah wartawan yang sudah lebih dahulu ditempatkan di suatu desk (lebih senior) terhadap wartawan yang lebih baru maupun yang lebih muda usianya. Selain senioritas, mereka yang bisa meminta atau 
mengkloning berita wartawan lain ini harus memiliki hubungan kedekatan dengan wartawan terkait (akrab, sudah berteman/mengenal lama). Jika ada wartawan baru kemudian meminta suatu berita kepada wartawan lain, maka biasanya yang bersangkutan akan menjadi bulan-bulanan setidaknya dinilai negatif karena dinilai tidak tahu etika, tidak bisa menempatkan diri, dan bentuk kepribadian buruk. Para wartawan sejatinya menyadari bahwa praktik kloning berita adalah bukan hal baik maka dari itu hal tersebut akan sangat ditentang apabila yang melakukan adalah wartawan baru. Reaksi ini beberapa kali penulis lihat saat masih bertugas sebagai wartawan di Kota Solo, dimana terdapat wartawan baru ditugaskan namun sudah "berani" meminta berita kepada wartawan lain yang juga sama-sama liputan di wilayah sama. Kloning berita adalah hal yang ditentang oleh para wartawan terutama bila dilakukan oleh wartawan baru karena praktik itu dinilai bukan sebagai bentuk pendidikan karakter dan mentalitas yang baik bagi wartawan bersangkutan.

"Jika masih baru saja sudah berani meminta berita, bagaimana nanti kalau sudah lama. Ya, khan, jadi males, masih muda mudah menyerah main enaknya saja. Enak aja meminta, kita yang capaicapai liputan. Siapa dia, ngga sopan. Perlu dididik tuh anak," kata narasumber pertama.

Komentar mengenai kasus di atas penulis coba tanyakan ke sejumlah narasumber lain dan mendapatkan jawaban kurang lebih sama. Para wartawan akan memafhumi praktik kloning dilakukan dengan alasan-alasan tertentu seperti terlambat dan tidak menjadi masalah bila berdasarkan asas kerelaan, pertemanan akrab.

2. Penyebab Praktik Kloning Berita
Ada banyak persoalan melatarbelakangi mengapa kloning berita di kalangan wartawan kemudian menjadi budaya. Berdasar pengalaman pernah bekerja sebagai jurnalis baik di media cetak maupun elektronik serta penuturan narasumber, praktik bagi berbagi berita terjadi karena adanya perasaan sungkan, simbiosis mutualisme, sanksi sosial, aturan perusahaan media, motif ekonomi.

2.1. Aturan Perusahaan Media

Sekalipun telah senior dan memiliki hubungan dekat dengan wartawan lain, tidak semua wartawan dapat atau mau melakukan praktik kloning. Hal ini utamanya berkenaan dengan aturan yang dibuat oleh masing-masing media. Ada memang media yang secara tegas melarang wartawannya untuk melakukan praktik kloning dan mewajibkan wartawannya untuk melakukan proses peliputan sendiri atas berita di dapat. Jika ketahuan melakukan kloning atau membuat berita bukan berdasar hasil kerja sendiri akan diberikan sanksi mulai dari peringatan, hingga pemecatan. Seorang wartawan koran lokal mengaku dikenai sanksi berupa cuti tanpa tugas selama sepekan karena narasumber yang ditulis dalam beritanya protes kepada redaksi akibat merasa tidak diwawancarai oleh wartawan bersangkutan. Faktanya, menurut penuturan wartawan bersangkutan, ia mendapatkan berita secara bersama-sama dengan wartawan lain melalui telepon. Salah satu wartawan melakukan proses wawancara kemudian meminta izin kepada narasumber (narasumber kedua) bahwa data itu akan dibagi dengan wartawan lain dengan menyebutkan nama-nama media wartawan yang ada di lokasi tersebut. Ada juga seorang wartawan yang kemudian memutuskan mengundurkan diri karena merasa tidak diperlakukan secara adil oleh medianya sebab protes dari narasumber yang merasa tidak diwawancarai bersangkutan. Menurut penjelasan narasumber kesepuluh, ia liputan by phone secara bersama-sama seperti halnya terjadi pada wartawan narasumber kesebelas.

Ada juga perusahaan media yang melarang wartawannya melakukan praktik 
kloning berita. Namun aturan itu berhenti sebatas di atas kertas dan sebagian besar wartawannya tetap melakukan praktik itu namun dengan syarat yakni beritanya tidak sama dan tidak mendatangkan risiko.

'Sakjane yo ora entuk tapi wis maklum. Lha piye maneh lha kabeh yo ngono. Penting ora podo nek nggonku, terus sing sekirane ora ana masalah" (sebenarnya tidak boleh tapi mau apalagi, sepertinya sudah memaklumi daripada tidak dapat berita. Yang penting tidak persis sama, diubah kalimatnya dan bukan berita yang berpotensi menimbulkan masalah. Kalau berita besar biasanya tetap konfirmasi atau digali lagi)" (narasumber kedelapan).

Ada media yang memang secara jelas menyebut dan menyampaikan tentang larangan kloning berita terhadap para wartawannya namun ada pula perusahaan media yang tidak memberikan larangan. Kloning berita dianggap sebagai pemafhuman daripada mengedepankan idealisme namun luput berita.

"Kaya gitu sudah biasa, para wartawan nasional juga begitu kayaknya. Yang penting dapat berita," narasumber ketiga.

"Malah ada produser bilang, terserah bagaimana caramu yang penting dapat berita. Sekarang dilihat posisi yang menguntungkan saja. Kalau misal ada kejadian bersamaan, semuanya kejadian besar. Bagaimana cara kita bisa dapat semuanya, ya, dengan cara seperti itu. Kami bagi, A dimana, B, dimana. Yang penting semua aman," menurut narasumber keempat.

2.2. Simbiosis Mutualisme dan "Sanksi Sosial"

Selain berkenaan dengan aturan masing-masing media, praktik kloning berita dilakukan dengan alasan menjaga hubungan baik (simbiosis mutualisme). Pada level ini, sebagian wartawan memang sengaja memberikan/membagi beritanya dengan wartawan lain dengan dasar pertemanan (setiakawan) juga hubungan saling menguntungkan. Mereka membagi beritanya terhadap wartawan lain sekalipun tidak diminta dengan dasar supaya di lain kesempatan apabila yang bersangkutan sedang sulit mendapatkan berita atau ketinggalan informasi /peliputan, dibantu (gantian) sebagaimana dilakukan saat itu. Praktik kloning sebenarnya tidak hanya terjadi karena diminta namun ada pula wartawan yang secara suka rela membagi informasi beritanya kepada wartawan lain. Selain karena pertimbangan setia kawan juga alasan lain. Penulis misalnya pernah membagi berita didapat dengan wartawan lain karena yang bersangkutan belum mendapat berita dianggap layak.

"eh, berita yang kamu kasih kemarin jadi headline, tapi aku takut banget kalau ketahuan dan ada yang protes," kata narasumber kelima.

Meski telah memiliki hubungan baik, berbagi informasi berita apalagi kloning tidak dilakukan apabila wartawan bersangkutan berasal dari media yang dianggap sebagai pesaing media tempat wartawan satunya bekerja.

"Nek nggonku nggonmu ki ora dianggep saingan (bagi mediaku, mediamu bukan kami anggap sebagai pesaing). Segmennya sudah beda. Nggak papa punyamu tayang duluan. Tapi jangan bilang-bilang lainnya ya" (narasumber keenam).

"Tempatku sepertinya tidak apa-apa, mbak, soalnya sana tahu kalau aku juga kerja untuk ...(menyebut nama media). Yang penting tidak sama kalimatnya dan didahulukan, dikirim yang pertama," ujar narasumber ketujuh.

Faktor lain adalah adanya sanksi sosial dari kalangan wartawan itu sendiri, dimana akan ada tindakan semacam "dikucilkan" dari suatu kelompok dimana ia biasa bertugas. Bentuk "pengucilan" itu biasanya berupa tidak diajak liputan bersama dan ditinggal bila ada peristiwa/isu besar. Ada informasiinformasi tertentu yang tidak akan begitu 
saja dengan mudah dibagi termasuk dalam mengenalkan terhadap narasumber. Ada semacam "batas" yang tercipta yang itu terjadi dengan sendirinya tanpa adanya komando dan mungkin memang terbentuk tidak dengan secara sengaja. Itu adalah praktik terjadi baik atas kesadaran melakukan secara sukarela karena praktik simbiosis mutualisme atau untuk menghindari sanksi sosial.

\subsection{Hubungan Senior-Yunior}

Praktik kloning juga terjadi akibat hubungan senior-yunior di kalangan wartawan. Biasanya akan muncul perasaan sungkan atau tidak enak pada diri wartawan yunior apabila tidak membagi berita dengan wartawan lain terutama yang lebih senior. Perasaan sungkan ini biasanya terjadi di kalangan wartawan pemula atau kalah senior baik dari segi usia maupun pengalaman menjadi wartawan. Mereka biasanya akan memiliki perasaan sungkan atau "tidak kuasa" menolak bila ada wartawan lain yang lebih senior memintai tolong berbagi berita.

2.4. Motif Ekonomi dan lainnya

Berdasarkan data dari narasumber empat, masih ada praktik satu lagi di mana wartawan memang sengaja membagi berita yang didapatnya (yang mungkin itu awalnya ekslusif) kepada wartawan/media lain karena pertimbangan keamanan dan juga ekonomi. Pertimbangan keamanan ini biasanya berkaitan dengan isu berita yang didapat biasanya bersifat sangat besar, yang memiliki nilai berita tinggi namun memiliki risiko tinggi pula terhadap keselamatan sang wartawan. Salah satu contoh, hal ini dilakukan salah seorang wartawan yang mendapatkan fakta akan adanya dugaan korupsi dilakukan kepala daerah. Wartawan bersangkutan tidak langsung membuat beritanya secara langsung namun membaginya dengan wartawan lain. wartawan yang ia pilih adalah wartawan dari media besar karena secara pasti akan mampu menangung risiko atas pemberitaan dilakukan. Wartawan tersebut membagi berita eksklusifnya dengan wartawan lain karena merasa tidak yakin akan adanya jaminan keamanan maupun keberlangsungan berita (follow up) dari perusahaan di tempatnya bekerja bila berita itu ia buat. Karena itu, ia memutuskan membuat beritanya setelah media besar dimaksud memberitakannya.

Sementara itu, menurut narasumber kelima, ada pula yang memang membagi beritanya karena merasa tidak perlu menyimpan beritanya itu secara ekslusif karena tidak seimbangnya antara "imbalan" dari perusahaan bersangkutan dengan risiko didapat. Imbalan itu baik berupa materi yakni berupa gaji, honor mengingat ada perusahaan media yang menerapkan sistem gaji berdasar berita tayang/dimuat. Atau pula karena kurangnya penghargaan secara verbal (pujian untuk mensemangati kinerja untuk terus produktif dan meningkatkan daya tempur demi mendapatkan berita yang ekslusif). Faktor imbalan secara materi yang dianggap kurang biasanya lebih menjadi pemicu wartawan membagi beritanya kepada wartawan media lain, yang terkadang dengan cara itu akan mendapatkan "imbalan" untuk tambahan penghasilan.

Perlu disadari bahwa tidak semua perusahaan media massa memiliki keuangan yang cukup untuk mampu menggaji wartawannya secara layak. Karena itulah, mereka tidak memaksakan para jurnalisnya bersikukuh pada kode etik yang telah ada khususnya dalam hal mendapatkan bahan berita. Ada pula, bahkan, perusahaan media yang tidak melarang (tahu) jika wartawannya bekerja ganda dalam arti bekerja untuk penyediaan berita lainnya.

"Tempat suamiku bekerja (menyebut salah satu nama media on-line) itu tidak apa-apa karena memang tidak mampu memberikan kesejahteraan kepada wartawannya. Jadi kerja ganda tidak apaapa. Dulu saat wawancara bahkan dibilangi kalau bekerja di sini jangan dijadikan sebagai tempat mencari nafkah 
utama. Jadi kalau cari berita ya dikirim buat satunya juga" (narasumber kedelapan).

Tentang motif ekonomi ini secara tidak langsung diakui narasumber 13. Ia seorang wartawan media nasional dengan tugas wilayah peliputan cukup luas meliputi beberapa kabupaten selain Kota Solo sendiri. Dengan pertimbangan praktis, ketidakmampuan tenaga dan waktu akhirnya ia mempercayakan bahan beritanya kepada wartawan lain yang bertugas secara khusus di suatu kota atau kabupaten tersebut. Sebagai gantinya, ia akan memberikan imbalan sejumlah uang terutama bila berita dimaksud tayang/muat di media wartawan bersangkutan.

"Lha kalau sekarang suruh megang 4 kabupaten apa ya mampu?. Coba pikir, jarak sini ke kabupaten lain itu sudah4060 kilometer. Waktu kita sudah habis di jalan. Bagaimana cara baginya? Belum kalau ada kejadian bersamaan. remuk balunge. Mending nanam orang, aman. Cukup kalau peristiwa besar kita ke sana, atau kalau ada order khusus dari kantor," kata narasumber kesembilan.

\section{Penutup}

Sekalipun

praktik-praktik sebagaimana tersebut di atas dijumpai di lapangan, tidak semua wartawan berbuat demikian. Banyak pula wartawan yang bekerja dengan mengedepankan profesionalisme dalam perolehan beritanya, dalam arti benar-benar liputan (berada di lokasi kejadian, mewancarai sendiri narasumber) dan menyusun beritanya sendiri sebelum akhirnya diserahkan ke redaksi. Banyak pula wartawan yang berjuang mati-matian dalam memperoleh berita agar berita yang didapatnya memang benar-benar ekslusif, berbeda dengan yang dimiliki wartawan lainnya, utamanya media lain. Lebih-lebih berita itu nantinya menjadi headline atau berita utama yang bisa menjadi berita bergulir dalam kurun cukup lama, yang bisa ditindaklanjut (follow-up) dari banyak sisi, atau bahkan di-follow-up oleh media lain. Berita itu akhirnya mampu membawa pengaruh besar bagi kehidupan masyarakat karena mampu mempengaruhi kebijakan pemerintah, misalnya. Ini akan menjadi suatu kepuasan tersendiri bagi sang wartawan. Baginya kerja ini tidak untuk sekadar mencari penghasilan, untuk dirinya sendiri. Tidak. Wartawan tidak bekerja untuk itu. Ia mengabdi kepentingan yang jauh lebih luas yakni masyarakat, publik. Masyarakat yang dimaksud tidak hanya pelanggan koran atau majalah atau bukan hanya mereka yang menjadi penonton siaran televisi, atau bukan hanya mereka yang menjadi pendengar setia radio. Lebih luas lagi, seluruh masyarakat (Kunto, 2006: 23-24).

Untuk menghindari adanya praktik bagi berbagi berita yang tujuan utamanya dikembalikan mendapat berita ekslusif, beberapa media menerapkan kebijakan tersendiri yakni menempatkan wartawannya secara khusus bertugas di wilayah-wilayah grassroot dan atau memiliki wartawan secara khusus yang memang hanya bertugas melakukan peliputan secara investigasi. Sementara, kebersamaan dengan wartawan lain juga dianggap penting untuk menjaga informasi agar tidak luput. Karenanya media tetap menempatkan wartawan mereka di tempattempat yang biasanya menjadi sumber berita semisal sumber pengambilan keputusan (Gubernuran, Pemkot, DPR-D), di mana di lokasi-lokasi itu biasa akan ditemui banyak wartawan dari berbagai media.

Melihat penyebab munculnya praktik kloning berita, penulis melihat sejatinya semua bermuara pada satu kata yakni profesionalitas. Praktik kloning berita tidak bisa sepenuhnya disalahkan kepada wartawan yang bertugas di lapangan. Dalam persoalan ini penulis melihat perusahaan media juga memiliki sumbangsih terhadap terjadinya praktik kloning berita mengingat jika dilihat dari penuturan sejumlah narasumber, ada 
semacam sikap menutup mata dari sebagian perusahaan media dengan menekankan memperoleh berita adalah hal lebih penting daripada menegakkan etika dan profesionalitas dalam proses peliputan berita. Memperoleh berita adalah penting namun menurut hemat penulis, lebih-lebih berita tersebut memiliki nilai berita tinggi sehingga membawa dampak besar bagi masyarakat. Namun memperoleh berita dengan upaya sendiri tentu akan lebih memuaskan dan berdasar pengalaman peneliti sebagai jurnalis, itu dapat dilakukan sekalipun memang butuh upaya lebih baik dalam hal waktu, pikiran maupun tenaga. Praktik kloning berita yang dilakukan kalangan wartawan dapat juga dianggap sebagai cermin bagaimana tingkat kesejahteraan wartawan bersangkutan yang otomatis menggambarkan pula kemampuan perusahaan media dalam memberikan kesejahteraan terhadap wartawannya. Seketat dan sebagus apapun perusahaan media dalam membuat aturan berkenaan perilaku atau operasional terhadap wartawannya, jika tidak diimbangi dengan imbalan sepadan maka aturan hanya akan berakhir di atas kertas. Kesejahteraan karyawan atau wartawan adalah cara yang cukup manjur untuk menjamin sebuah aturan dapat ditegakkan dengan sungguhsungguh. Hal ini merujuk pada hasil penelitian Andrik Purwasito (2008) mengenai kompetensi wartawan di Kota Surakarta yang menyimpulkan jika semakin baik perhatian dan kepedulian, fasilitas kerja dan jaminan hidup dari pengelola media terhadap wartawan sebagai bagian penting dari peningkatan profit perusahaan, akan semakin baik kualitas atau kompetensi wartawan, dan semakin berkualitas produk jurnalistiknya.

Sumbangsih penyelenggara media terhadap praktik kloning berita selain pada persoalan tersebut di atas, juga berkaitan dengan tingkat kesadaran serta kemauan tiap perusahaan media untuk terus mengembangkan kualitas para wartawannya. Peningkatan kualitas ini selain melalui pendidikan (pelatihan) internal juga eksternal baik yang diselenggarakan lembaga pendidikan tinggi maupun non pendidikan tinggi. Banyak perusahaan media yang memilih pola instan atau asal comot dalam perekrutan karyawannya tanpa mengedepankan latar belakang pendidikan dengan mementingkan pengalaman bekerja sehingga tidak perlu lagi meluangkan waktu dan biaya untuk memberikan pelatihan terhadap wartawannya. Akibatnya para wartawan bekerja menurut pola lama atau meniru (melihat) bagaimana lingkungan mereka bekerja tanpa pembekalan tentang ramburambu jurnalistik serta penegakkan aturan dari perusahaan media (Kasatriyanto, 2009), (Kartinawati, 2014).

Dari paparan di atas dapat kita lihat jika upaya penegakkan profesionalitas kerja tidak bisa ditimpakan pada satu pihak dalam hal ini hanya kepada wartawan di lapangan namun juga terhadap penyelenggara media. Memang dibutuhkan kesadaran dan kemauan dari dua belah pihak agar profesionalitas dalam mendapatkan bahan berita ini terwujud, lebih-lebih masalah kloning berita bukanlah masalah yang dapat dibawa ke ranah hukum namun sebatas persoalan etika yang kesemuanya hanya dapat dikembalikan ke masing-masing wartawan dan perusahaan penyelenggara media. Masyarakat juga tidak terkena dampak secara langsung atas praktik ini namun begitu menurut penulis ini penting sebagai bentuk kejujuran dan tanggung jawab moral terhadap publik atas suatu karya jurnalistik.

\section{Daftar Pustaka}

Adams, T. E., Jones, S. H., \& Ellis, C. (2015). Autoethnography: Understanding Qualitative Research. New York: Oxford University Press. 
Chang, H. (2008). Autoethnograpy as a Method. California: Left Coast Press, Inc.

Hume, Lynne, Mulcock, Jane. (2004). Anthropologists in the Field. Cases in Participant Observation. USA: Columbia University.

Kunto A., A.A. (2006). Cara Gampang Menjadi Wartawan. Yogyakarta: GalangPress.

Kriyantono, Rachmat. (2010). Tehnik Praktis Riset Komunikasi. Jakarta: Prenada Kencana.

Littlejohn, Stephen W., and Foss, Karen A. (2011). Theories of Human Communication $\quad\left(10^{\text {th }} \quad\right.$ edition $)$. Illinois: Waveland Press, Inc.

Lynch, Michael. (1993). Scientific Practice and Ordinary Action: Ethnomethodology and Social Studies of Science. Cambridge UP.

Syah, Sirikit. 2011. Rambu-Rambu Jurnalistik. Yogyakarta: Pustaka Pelajar.

De Vreese, Claes. (2004). The Effects of Strategic News on Political Cynicism, Issue Evaluations, and Policy Support: A Two-Wave Experiment. Journal of Mass Communication and Society. 7(2).
O’Hara, Kate. (June 2014). From Filtering to Freire: Critical Use of the Internet in Urban Classrooms. Journal of Arts and Humanities (JAH), Volume 3, No. 6.

Kartinawati, Erwin. (2014). Kualitas Berita Televisi Lokal: Analisis Kualitas Berita Televisi Lokal dan Faktor Penyebabnya. Tesis. Universitas Sebelas Maret, Surakarta.

Kasatriyanto, Bambang. (2009). Garda Depan (Karya Kontributor sebagai Garda Depan Pemberitaan Televisi di Daerah di tengah Persaingan dan Bisnis TV yang Semakin Ketat). Tugas Akhir. Universitas Sebelas Maret, Surakarta.

Purwasito, Andrik. 2008. Pola Berpikir Wartawan Lokal terhadap Standar Kompetensi: Kajian Eksploratif terhadap Wartawan di 4 Media Cetak di Surakarta. Laporan Penelitian. Surakarta: Fisip UNS.

Undang-Undang RI tentang Pers No 40 tahun 1999. 